\title{
Design, synthesis and biological evaluation of novel benzodioxole derivatives as COX inhibitors and cytotoxic agents
}

\author{
Mohammed Hawash $^{1 *}$, Nidal Jaradat ${ }^{1} \mathbb{B}$, Saba Hameedi ${ }^{1}$ and Ahmed Mousa ${ }^{2}$
}

\begin{abstract}
Non-steroidal anti-inflammatory drugs are among the most used drugs. They are competitive inhibitors of cyclooxygenase (COX). Twelve novel compounds (aryl acetate and aryl acetic acid groups) were synthesized in this work in order to identify which one was the most potent and which group was most selective towards COX 1 and COX 2 by using an in vitro COX inhibition assay kit. The cytotoxicity was evaluated for these compounds utilizing MTS assay against cervical carcinoma cells line (HeLa). The synthesized compounds were identified using FTIR, HRMS, ${ }^{1} H-N M R$, and ${ }^{13} \mathrm{C}-N M R$ techniques. The results showed that the most potent compound against the COX 1 enzyme was $4 f$ with $I C_{50}=0.725 \mu \mathrm{M}$. The compound 3b showed potent activity against both $\operatorname{COX} 1$ and $\mathrm{COX} 2$ with $I C_{50}=1.12$ and $1.3 \mu \mathrm{M}$, respectively, and its selectivity ratio (0.862) was found to be better than Ketoprofen (0.196). In contrast, compound $4 \mathrm{~d}$ was the most selective with a COX1/COX2 ratio value of 1.809 in comparison with the Ketoprofen ratio. All compounds showed cytotoxic activity against the HeLa Cervical cancer cell line at a higher concentration ranges (0.219$1.94 \mathrm{mM}$ ), and the most cytotoxic compound was $3 e$ with a $C_{50}$ value of $219 \mu \mathrm{M}$. This was tenfold more than its $\mathrm{IC}_{50}$ values of 2.36 and $2.73 \mu \mathrm{M}$ against COX1 and COX2, respectively. In general, the synthesized library has moderate activity against both enzymes (i.e., COX 1 and $\mathrm{COX} 2$ ) and ortho halogenated compounds were more potent than the meta ones.
\end{abstract}

Keywords: Benzodioxole, COX, Ketoprofen

\section{Introduction}

Some of the most used analgesics are non-steroidal antiinflammatory drugs (NSAIDs) that target the cyclooxygenase (COX) enzymes. NSAIDs are used for various therapeutic purposes globally. Due to their wide pharmacological effects, including analgesic, anti-inflammatory and antipyretic effects, they are investigated as being some of the best choices for treating different diseases like arthritis and rheumatism, and they are widely used as analgesics. Actually, acetyl salicylic acid (ASA), one of the members of this family, has been used for more than

\footnotetext{
*Correspondence: mohawash@najah.edu

${ }^{1}$ Department of Pharmacy, Faculty of Medicine and Health Sciences, An-

Najah National University, P.O. Box 7, Nablus 00970, Palestine

Full list of author information is available at the end of the article
}

a 100 years $[1,2]$. The biosynthesis of prostaglandin $\mathrm{H} 2$ from arachidonic acid is catalysed by COX enzymes [3]. Prostaglandin $\mathrm{H} 2$ is the main component in the formation of other prostaglandins, such as thromboxane and prostacyclin, which play important roles in different biological responses $[4,5]$. In fact, COX1 and COX2 are the two major isoforms of COX membrane-bound enzymes [6]. COX1 is involved in the biosynthesis of important prostaglandins which maintain the constant functions in the body, essentially in the cardiovascular and gastrointestinal systems [7]. Moreover, COX2 is an enzyme catalyst that is overexpressed in several pathophysiological events such as hyperalgesia, inflammation, and cancer $[8,9]$. The structures of COX1 and COX2 enzymes are $67 \%$ identical in amino acid chains. The main difference between the two enzymes is the presence of isoleucine 
(Ilu523) in COX1 instead of valine (Val523) in COX2. This allows $25 \%$ greater available space in the binding region of COX2 in comparison to COX1 [10]. All of these data encourage the researchers to focus their efforts to the find COX2 selective inhibitors in order to improve treatment efficacy and to reduce the side effects that are associated with the use of non-selective inhibitors of these enzymes [11-13].

COX2 enzyme is associated with carcinogenesis and inflammatory diseases. It is suspected to induce tissue invasion of tumours, angiogenesis, and resistance to apoptosis. Moreover, COX2 plays an important role in the innate and adaptive immune response, and it contributes to immune evasion and resistance to cancer immunotherapy. However, COX inhibitors can facilitate a benefit to patients from addition of COX inhibitors when compared to standard chemotherapy [14].

A large number of agents with different structural features were produced in the discovery efforts of new COX2 selective inhibitors. A lot of classical non-selective NSAIDs were synthesized, approved, and used broadly, such as Ibuprofen, Naproxen, and Ketoprofen (Fig. 1), but their selectivity is too low against COX2/COX1 [15], and the previous studies were implemented to synthesize more selective agents as COX2 inhibitors by using different methods and structures [16].

According to the World Health Organization (WHO) surveys, cancer is one of the leading causes of death around the globe, and it was responsible for about 10 million deaths in 2018 [17, 18]. Around 1 in 6 people died from cancer, which is considered the largest cause of death. This is a considerably alarming estimate. WHO has recognized that 1.16 trillion US dollars were spent on the prevention and treatment of cancer in 2010 alone, and that number has increased dramatically over the years [17]. These important statistics are the result of erratic human behaviours such as smoking, which is<smiles>CC(C(=O)O)c1cccc(C(=O)c2ccccc2)c1</smiles>

Ketoprofen<smiles>CC(=O)Oc1ccccc1C(=O)O</smiles>

Aspirin<smiles>COc1ccc2cc([C@H](C)C(=O)O)ccc2c1</smiles>

Fig. 1 Classical NSAIDs with $\mathrm{COOH}$ functional group associated with lung cancer, fruits and vegetables contaminated with pesticides and phyto-growth hormones, and the unhealthy lifestyles of modern people as well as some physical carcinogens such as radiation, some chronic diseases such as diabetes, and some infectious illnesses such Hepatitis B and C viral infections [19].

The heterocycle-containing agents have several pharmacological effects including anticancer [20, 21], antiinflammatory [22], antioxidant [23] and analgesic effects [24]. Therefore, the Benzodioxole containing compounds (Fig. 2) have different biological activities such as anticancer, anti-tuberculosis, anti-microbial, anti-epileptic, and analgesic activity [25-30]. Various tricyclic compounds and Ketoprofen like structures were synthesized and evaluated as COX enzyme inhibitors [31, 32]. The current work aims to synthesize new compounds with a Benzodioxole core structure in two final product groups with different halogen atoms and aryl acetate and aryl acetic acid (Fig. 3), to evaluate their COX1 and COX2

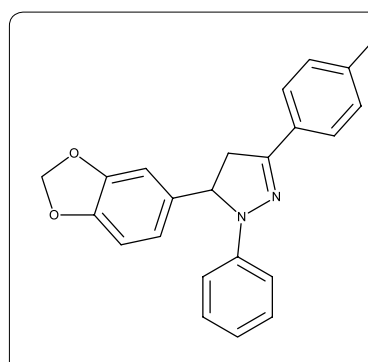

No.1

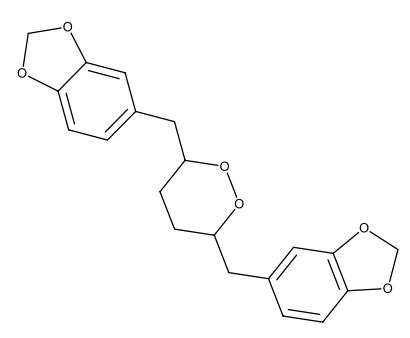

No.2

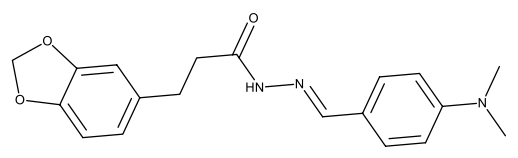

No. 3

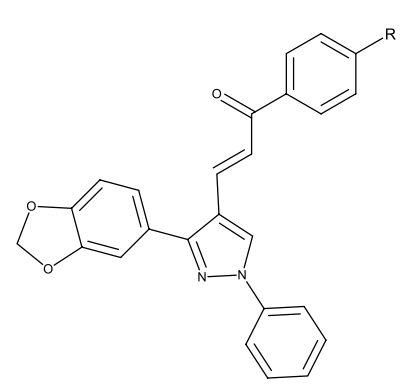

No. 4

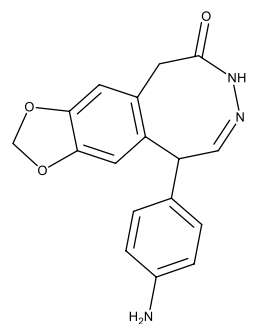

No. 5
Fig. 2 Structures of benzodioxol derivatives having various biological activities 


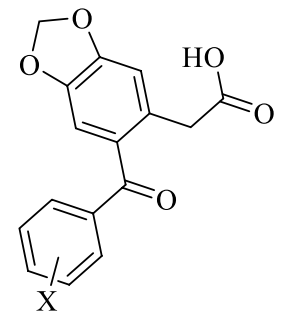

Aryl acetic acid

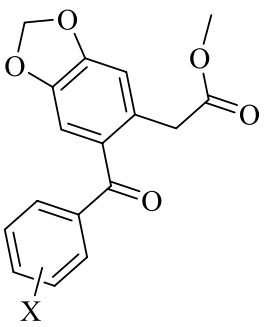

Aryl acetate
Fig. 3 Halogenated Ketoprofen analogues as aryl acetic acid and aryl acetate

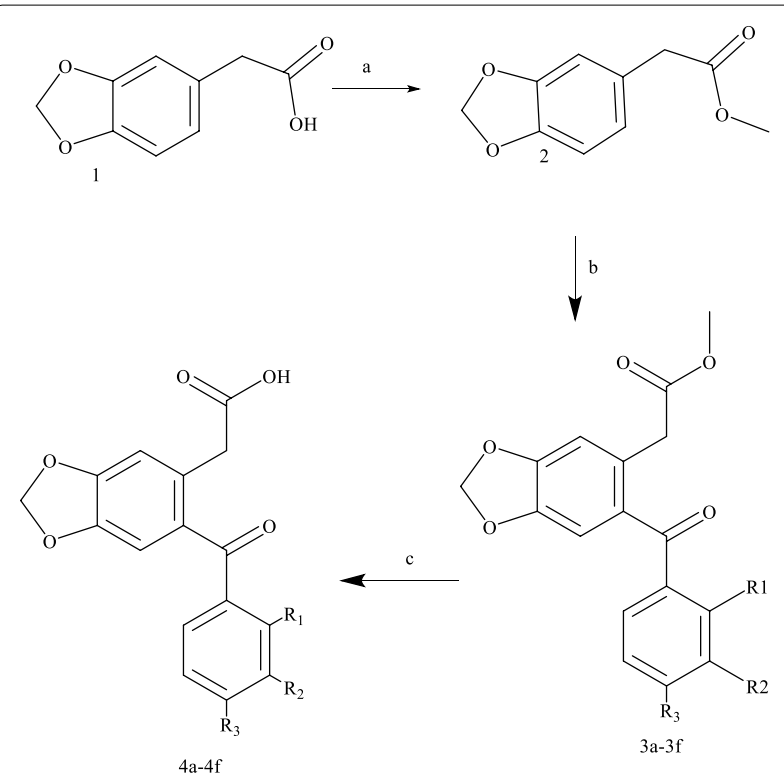

Scheme 1 The reaction steps a methanol, oxalyl chloride $\mathbf{b}$ DCM, $\mathrm{P}_{2} \mathrm{O}_{5}$, aryl-carboxylic acid, c MeOH/THF/ $\mathrm{H}_{2} \mathrm{O}, \mathrm{NaOH}$ reflux

inhibitory activity and to evaluate the synthesized compounds' cytotoxic effects.

\section{Results and discussion \\ Chemistry}

The Benzodioxole aryl acetate derivatives (3a-3f) and acetic acid derivatives (4a-4f) were synthesized as outlined in Scheme 1. The methyl 3,4-(methylenedioxy) phenylacetate (2) was generated by an esterification reaction of 3,4-(methylenedioxy) phenylacetic acid (1). To produce the ester (2), oxalyl chloride was added dropwise to methanol solvent and stirred for half an hour in an ice bath [33, 34]. The IR spectra of the ester (2) showed the disappearance of the broad band that belonged to the acetic acid group of (1). The aryl acetate $\mathbf{3 a}-\mathbf{3 f}$ compounds were synthesized by dissolving the ester (2) in dichloromethane with benzoic acid derivatives in the presence of an excess of phosphorus pentoxide and stirring at room temperature for approximately $18 \mathrm{~h}$. The ${ }^{1} \mathrm{H}$-NMR spectrum data of these compounds showed 5-7 protons (depend on the Halogen atoms for each compound) in the aromatic area, 2 protons around $6.13 \mathrm{ppm}$ singlet peaks for $\mathrm{O}-\mathrm{CH}_{2}-\mathrm{O}$ of benzodioxole and 5 protons were observed in area 3.40 and $3.80 \mathrm{ppm}$ for $-\mathrm{CH}_{2}-$ $\mathrm{CO}-\mathrm{CH}_{3}$. According to the ${ }^{13} \mathrm{C}-\mathrm{NMR}$ spectrum, $\mathrm{C}$ signal of carbonyl groups was found around 195 and $171 \mathrm{ppm}$, and at 37-51 ppm two signals of aliphatic carbon were observed. The Benzodioxole acetic acid derivatives (4a4f) were synthesized by hydrolysis reaction of the ester compounds 3a-3f using $\mathrm{NaOH}$ [35] (see Scheme 1). The ${ }^{1} \mathrm{H}$-NMR spectrum data showed one proton with singlet peak around $12 \mathrm{ppm}(-\mathrm{COOH}), 2$ protons around $6.13 \mathrm{ppm}$ singlet peaks for $\mathrm{O}-\mathrm{CH}_{2}-\mathrm{O}$ of benzodioxole and 2 protons were observed in area $3.40-3.78 \mathrm{ppm}$ for $\mathrm{CH}_{2}-\mathrm{COOH}$. However, ${ }^{13} \mathrm{C}-\mathrm{NMR}$ spectrum data showed $\mathrm{C}$ signal of carbonyl groups around 197 and $172 \mathrm{ppm}$.

\section{Cyclooxygenase inhibition activity}

The synthesized compounds have a structure that is similar to Ketoprofen, and because of that Ketoprofen was used as a positive control in the COX inhibition analysis of the synthesized library. All Benzodioxole acetate structures with halogens $(\mathrm{Br}, \mathrm{Cl}, \mathrm{I} ; \mathbf{3 b}-\mathbf{3 f})$ on the phenyl ring showed better activity against $\mathrm{COX} 1\left(\mathrm{IC}_{50} 1.12-\right.$ $27.06 \mu \mathrm{M})$ than acetic acid Benzodioxole with halogens $\left(\mathrm{IC}_{50} 4.25-33.7 \mu \mathrm{M} ; \mathbf{4 b}-\mathbf{4 e}\right)$, except $\mathbf{4 f}$ which showed the most potent inhibitory activity $\left(\mathrm{IC}_{50}=0.725 \mu \mathrm{M}\right)$ against the COX1 enzyme. However, the acetic acid Benzodioxole compound without a halogen (4a) showed stronger inhibition activity toward cyclooxygenase enzymes COX1 and COX2 (1.45 and $3.34 \mu \mathrm{M}$, respectively) than acetate Benzodioxole without a halogen compound (3a) toward COX1 and COX2 (12.32 and $14.34 \mu \mathrm{M}$, respectively). However, all Benzodioxole acetate structures with halogens (3b-3f) showed better activity against COX2 $\left(\mathrm{IC}_{50} 1.30-37.45 \mu \mathrm{M}\right)$ than acetic acid Benzodioxole with halogens $\left(\mathrm{IC}_{50} 2.35-39.14 \mu \mathrm{M} ; \mathbf{4 b}-\mathbf{4 f}\right)$ as presented in Table 1.

\section{Cytotoxic evaluation}

An MTS assay was used to determine the cytotoxic effect of Benzodioxole derivatives on HeLa (cervical carcinoma cells). As shown in Table 1, four different concentrations were used $(2,1,0.5$, and $0.1 \mathrm{mM})$ to investigate the cytotoxicity of the compounds. Actually, all compounds showed inhibition of cell growth at relatively high concentrations in comparison to the $\mathrm{IC}_{50}$ of $\mathrm{COX}$ enzyme. 
Table $1 \mathrm{IC}_{50}$ inhibition of $\mathrm{COX} 1$ and $\mathrm{COX} 2$, Selectivity ratio for $\mathrm{COX} 1 / \mathrm{COX} 2$, and the $\mathrm{CC}_{50}$ on HeLa cancer cell line of the synthesized compounds

\begin{tabular}{|c|c|c|c|c|c|c|c|c|}
\hline \multirow[b]{2}{*}{ Codes } & $\mathrm{R}_{3}$ & \multirow[b]{2}{*}{ R1 } & \multirow[b]{2}{*}{ R2 } & \multirow[b]{2}{*}{ R3 } & \multicolumn{2}{|c|}{$\begin{array}{l}\text { The } I C_{50} \text { in } \mu \mathrm{M} \text { of } \operatorname{COX} 1 \\
\text { and } \operatorname{COX} 2\end{array}$} & \multirow[t]{2}{*}{ COX1/COX2 Ratio } & \multirow{2}{*}{$\begin{array}{l}\text { HeLa Cell } \mathrm{CC}_{50} \\
\text { in milli-molar } \\
\mathrm{CC}_{50}\end{array}$} \\
\hline & $x$ & & & & $\operatorname{cox} 1$ & $\operatorname{cox} 2$ & & \\
\hline $3 a$ & $\mathrm{O}-\mathrm{CH} 3$ & $\mathrm{H}$ & $\mathrm{H}$ & $\mathrm{H}$ & 12.320 & 14.340 & 0.859 & 1.49 \\
\hline $3 b$ & $\mathrm{O}-\mathrm{CH} 3$ & । & $\mathrm{H}$ & $\mathrm{H}$ & 1.120 & 1.300 & 0.862 & 0.228 \\
\hline $3 c$ & $\mathrm{O}-\mathrm{CH} 3$ & $\mathrm{H}$ & 1 & $\mathrm{H}$ & 27.060 & 37.450 & 0.723 & 1.79 \\
\hline $3 d$ & $\mathrm{O}-\mathrm{CH} 3$ & $\mathrm{Br}$ & $\mathrm{H}$ & $\mathrm{H}$ & 1.3 & 1.45 & 0.897 & 1.61 \\
\hline $3 e$ & $\mathrm{O}-\mathrm{CH} 3$ & $\mathrm{H}$ & $\mathrm{Br}$ & $\mathrm{H}$ & 2.360 & 2.730 & 0.864 & 0.219 \\
\hline $3 f$ & $\mathrm{O}-\mathrm{CH} 3$ & $\mathrm{Cl}$ & $\mathrm{H}$ & $\mathrm{Cl}$ & 5.180 & 4.100 & 1.263 & 0.949 \\
\hline $4 a$ & $\mathrm{OH}$ & $\mathrm{H}$ & $\mathrm{H}$ & $\mathrm{H}$ & 1.450 & 3.340 & 0.434 & 1.94 \\
\hline $4 b$ & $\mathrm{OH}$ & I & $\mathrm{H}$ & $\mathrm{H}$ & 7.670 & 30.700 & 0.250 & 0.697 \\
\hline $4 c$ & $\mathrm{OH}$ & $\mathrm{H}$ & 1 & $\mathrm{H}$ & 33.700 & 39.140 & 0.861 & 1.049 \\
\hline $4 d$ & $\mathrm{OH}$ & $\mathrm{Br}$ & $\mathrm{H}$ & $\mathrm{H}$ & 4.250 & 2.350 & 1.809 & 0.547 \\
\hline $4 e$ & $\mathrm{OH}$ & $\mathrm{H}$ & $\mathrm{Br}$ & $\mathrm{H}$ & 7.110 & 49.300 & 0.144 & 0.437 \\
\hline $4 f$ & $\mathrm{OH}$ & $\mathrm{Cl}$ & $\mathrm{H}$ & $\mathrm{Cl}$ & 0.725 & 4.290 & 0.169 & 1.019 \\
\hline Ketoprofen & & & & & 0.031 & 0.158 & 0.196 & \\
\hline
\end{tabular}

P-values for the experiments $p<0.05$

The $\mathrm{CC}_{50}$ were in the range between 0.219 and $1.79 \mathrm{mM}$. The most cytotoxic compound was $\mathbf{3 e}$ with a $\mathrm{CC}_{50}$ value of $219 \mu \mathrm{M}$.

\section{SAR study}

All ortho halogenated compounds $\mathbf{3 b}, \mathbf{3 d}, \mathbf{4 b}$, and $\mathbf{4 d}$ showed better activity with lower $\mathrm{IC}_{50}$ values than their meta halogenated compounds 3c, 3e, 4c and 4d. For example the $\mathrm{IC}_{50}$ values of compound $\mathbf{3 b}$ (ortho-halogenated) against both COX1 and COX2 were 1.120 and $1.300 \mu \mathrm{M}$ in comparison with $\mathbf{3 d}$ (meta-halogenated) which were 27.060 and $37.450 \mu \mathrm{M}$, respectively. This depended on the theory that the ortho-halogenated compounds can make the second aromatic ring non-coplanar with the first aromatic ring, which is ideal for the COX inhibitory activity. All ester-mono halogenated compounds (ortho or meta; 3b, 3c, 3d \& 3e) have better COX inhibitory activity than acetic acid mono-halogenated compounds (ortho or meta; $\mathbf{4 b}, \mathbf{4 c}, \mathbf{4 d} \& \mathbf{4 e}$ ). Except for compound $\mathbf{4 b}$, all other ortho-halogenated compounds (3b, 3d, and 4d) showed better selectivity ratios (COX1/ COX2) than meta-halogenated compounds. The most potent compound against COX1 enzyme was the acetic acid di-halogenated (2,4-dichloro) compound 4f. The ortho-iodo ester compound $3 \mathbf{b}$ was potent against COX2 enzyme with a good selectivity ratio $(0.862)$.
There is no clear relationship between the ortho versus meta halogen and the cytotoxicity results. Generally, the halogenated compounds are more cytotoxic than non-halogenated (3a \& 4a). The most cytotoxic compound was compound $\mathbf{3 e}$ (ester with $\mathrm{Br}$ on meta position; $\mathrm{CC}_{50}=0.219 \mathrm{mM}$ ). It was more toxic than compound 3d (ester with $\mathrm{Br}$ on ortho), and the same relation was found between $4 \mathbf{e}$ and $\mathbf{4 d}$, respectively. In contrast, the ortho iodo halogenated compounds ( $\mathbf{3} \mathbf{b}$ and $\mathbf{4 b}$ ) were more toxic than meta iodo halogenated compounds (3c \& 4c).

In this study we can observe that our synthesized compounds have inhibition activity against both COX1 and COX2 enzymes better than some tricyclic compounds synthesized by other research teams. As published by Caliskan et al., one of pyrazol-3-propanoic acids derivatives was the most active compound in this series, and it showed a selectivity ratio of 0.93 and activity against $\mathrm{COX} 1$ and $\mathrm{COX} 2$ with an $\mathrm{IC}_{50}$ value relatively close to our results (1.5 and $1.6 \mu \mathrm{M}$, respectively). However, the inhibitory activity against COX1 for most of our synthesized compounds were very close to or better than their tested compound [36]. In another study by Assali et al., a series of pyrazole and triazole derivatives were synthesized, and one of their triazole derivatives was considered to be a highly selective COX2 inhibitor with a high selectivity ratio (162.5) [16]. Comparing our results with other studies, the results of this study clearly demonstrate 
that the synthesized agents have good inhibition activity against both COX1 and COX2 enzymes with relatively low $\mathrm{IC}_{50}$ values, and the $\mathrm{COX}$ selectivity ratio of the compounds synthesized in this study were better than approved drugs like ketoprofen or aspirin.

\section{Conclusion}

The synthesized compounds showed moderate activity against COX1 and COX2 enzymes. However, most compounds have better COX2 inhibition selectivity compared to Ketoprofen. The results showed a promising group of compounds having a Benzodioxole moiety. They had better COX2 selectivity compared with Ketoprofen, and this may be due to the bigger moiety (Benzodioxole) in the synthesized compound in comparison with phenyl moiety in Ketoprofen. Future plans should include docking studies and synthesizing more analogues of this core structure to study the structure-activity relationship. This is required in order to improve their COX inhibitory activity and to achieve a better COX2 selectivity ratio. All compounds 3a-4f showed cytotoxic activity on the HeLa cancer cell line at higher doses. However the effective doses towards COX enzyme were at least lesser 10 times greater than the cytotoxic concentrations.

\section{Experimental section}

\section{Chemicals and instruments}

All chemicals were purchased from Sigma-Aldrich and Alfa Aesar. Melting points were determined with an SMP-II Digital Melting Point Apparatus and are uncorrected. IR spectra were obtained using a Perkin Elmer Spectrum 400 FTIR/FTNIR spectrometer. ${ }^{1} \mathrm{H}-\mathrm{NMR}$ and ${ }^{13} \mathrm{C}$-NMR spectra were recorded in DMSO-d6 and were performed on two NMR instruments. The first was a Bruker $500 \mathrm{MHz}$-Avance III High-Performance Digital FT-NMR spectrometer at the Faculty of Science, Department of Chemistry, The University of Jordan, Jordan (it was used for the ${ }^{1} \mathrm{H}-\mathrm{NMR}$ of just one compound, $3 \mathbf{e}$ ). The second was a Bruker $300 \mathrm{MHz}$-Avance III HighPerformance Digital FT-NMR spectrometer at the NMR facility at the Doping and Narcotics Analysis Laboratory of the faculty of pharmacy, Anadolu University, Turkey (it was used for both ${ }^{1} \mathrm{H}$-NMR and ${ }^{13} \mathrm{C}$-NMR for the other compounds). Tetramethylsilane was used as the internal standard. All chemical shifts were recorded as d (ppm). High resolution mass spectral data (HRMS) were collected using a Waters LCT Premier XE Mass Spectrometer (high sensitivity orthogonal acceleration time-of-flight instrument) using ESI $(+)$ method (The instrument was coupled to an AQUITY Ultra Performance Liquid Chromatography system (Waters Corporation, Milford, MA, USA) at the Pharmacy Faculty Gazi University AnkaraTurkey. The silica gel used for the flash chromatography column had a pore size of $60 \AA$ and $230-400$ mesh particle size, $40-63 \mu \mathrm{m}$ particle size. The inhibitory activity of ovine COX1 and human recombinant COX2 enzymes was determined using a COX inhibitor screening assay kit No. 560131 (Cayman Chemical, USA). The yellow product of this enzymatic reaction was determined using a UV spectrophotometer with a Microplate Reader (BioRad, Japan) at a wavelength of $415 \mathrm{~nm}$. HeLa Cervical Carcinoma cell line was purchased from ATCC (ATCC $\left.{ }^{\circledR} \mathrm{CCL}-2^{\mathrm{TM}}\right)$, and the cyototoxicty test of the cell viability was assessed by the CellTilter $96^{\circledR}$ Aqueous One Solution Cell Proliferation (MTS) assay according to the manufacturer's instructions (Promega Corporation, Madison, WI) (Additional file 1).

\section{Chemistry method}

Synthesis of methyl 2-(2H-1,3-benzodioxol-5-yl) acetate synthesis 2

The 3,4-(methylenedioxy)phenylacetic acid (1) (8 g, $44.40 \mathrm{mmol}$ ) was dissolved in methanol, then it was cooled in an ice bath to $0{ }^{\circ} \mathrm{C}$. Then oxalyl chloride $(4 \mathrm{~mL}$, $46.80 \mathrm{mmol}$ ) was added dropwise, and the reaction mixture was stirred for $30-45 \mathrm{~min}$. The reaction mixture was then evaporated under vacuum and the resulting residue was diluted with ethyl acetate solvent and washed with saturated sodium bicarbonate $\left(\mathrm{NaHCO}_{3}\right)$ and distilled water, sequentially. The organic layer was dried with sodium sulphate, then filtered and evaporated again to concentrate it. In the last step, it was purified by silica gel column chromatography by using a hexane:ethyl acetate solvent system (50\%:50\%). The resulting compound (2) was a yellow oil with $94 \%$ yield.

\section{General synthesis procedure for ketoester (3a-3f) derivatives} The benzoic acid derivatives $(1.46 \mathrm{~g}, 6.68 \mathrm{mmol})$ and phosphorus pentoxide ( $5 \mathrm{~g}$ ) were added to a stirred solution of dichloromethane $(60 \mathrm{~mL})$ and compound (2) $(1 \mathrm{~g}, 5.14 \mathrm{mmol})$. Then, the mixture was stirred at room temperature for $18 \mathrm{~h}$ before distilled water $(60 \mathrm{~mL})$ was cautiously added, and the mixture was extracted with ethyl acetate twice $(60 \mathrm{~mL})$. Then, the organic layer was separated and treated with $1 \mathrm{M} \mathrm{NaOH}(60 \mathrm{~mL})$, brine $(60 \mathrm{~mL})$, and twice with $60 \mathrm{~mL}$ of distilled water. The organic layer was dried with sodium sulphate, filtered, evaporated under vacuum, and then purified by silica gel column chromatography with different solvent systems.

\section{Methyl 2-(6-benzoylbenzo[d][1,3]dioxol-5-yl)acetate} (3a) Purified by silica gel column chromatography using $n$-hexane: ethyl acetate solvent system (3:2). Crude yellow semi solid, Yield 75\%; ESI-MS: 299.0919 (100), 300 (20), 301 (2), For $\mathrm{C}_{17} \mathrm{H}_{15} \mathrm{O}_{5}$. IR (FTIR/FTNIR-ATR): $1737 \mathrm{~cm}^{-1}$ ester carbonyl $(\mathrm{C}=\mathrm{O}), 1661 \mathrm{~cm}^{-1}$ keton carbonyl $(\mathrm{C}=\mathrm{O})$. 
${ }^{1} \mathrm{H}$ NMR (DMSO-d $\left.\mathrm{d}_{6}, 300 \mathrm{MHz}\right) \delta \mathrm{ppm}: 7.62-7.67(3 \mathrm{H}, \mathrm{m}$, $\mathrm{Ar}-\mathrm{H}), 7.52(2 \mathrm{H}, \mathrm{t}, J=7.8 \mathrm{~Hz}, \mathrm{Ar}-\mathrm{H}), 7.05(1 \mathrm{H}, \mathrm{s}, \mathrm{Ar}-\mathrm{H})$, $6.89(1 \mathrm{H}, \mathrm{s}, \mathrm{Ar}-\mathrm{H}), 6.12\left(2 \mathrm{H}, \mathrm{s}, \mathrm{O}-\mathrm{CH}_{2}-\mathrm{O}\right), 3.74(2 \mathrm{H}, \mathrm{s},-$ $\mathrm{CH}_{2}-\mathrm{C}=\mathrm{O}$ ), $3.47\left(3 \mathrm{H}, \mathrm{s}, \mathrm{O}-\mathrm{CH}_{3}\right) \cdot{ }^{13} \mathrm{C}-\mathrm{NMR}$ (DMSO-d ${ }_{6}$, $75 \mathrm{MHz}) \delta$ ppm: 196.53, 171.61, 149.66, 146.04, 138.08, $133.39,131.59,130.21,130.00,129.73,129.44,128.95$, $112.66,110.34,102.45,51.89$, and 38.36 .

Methyl 2-(6-(2-iodobenzoyl)benzo[d][1,3]dioxol-5-yl)acetate $(3 b)$ Purified by silica gel column chromatography using $n$-hexane: ethyl acetate solvent system (1:1). Semi solid product, Yield 90\%. ESI-MS: 424.9875 (100), 425.99 (20), for $\mathrm{C}_{17} \mathrm{H}_{14} \mathrm{IO}_{5}$. IR (FTIR/FTNIR-ATR): $1740 \mathrm{~cm}^{-1}$ ester carbonyl $(C=O), 1659 \mathrm{~cm}^{-1}$ keton carbonyl $(C=O)$. ${ }^{1} \mathrm{H}$ NMR (DMSO- $\left.\mathrm{d}_{6}, 300 \mathrm{MHz}\right) \delta$ ppm: $7.95(1 \mathrm{H}, \mathrm{d}$, $J=7 \mathrm{~Hz}, \mathrm{Ar}-\mathrm{H}), 7.51(1 \mathrm{H}, \mathrm{t}, J=7.5 \mathrm{~Hz}, \mathrm{Ar}-\mathrm{H}), 7.23-7.30$ $(2 \mathrm{H}, \mathrm{m}, \mathrm{Ar}-\mathrm{H}), 7.11(1 \mathrm{H}, \mathrm{s}, \mathrm{Ar}-\mathrm{H}), 6.64(1 \mathrm{H}, \mathrm{s}, \mathrm{Ar}-\mathrm{H})$, $6.13\left(2 \mathrm{H}, \mathrm{s}, \mathrm{O}-\mathrm{CH}_{2}-\mathrm{O}\right), 3.92\left(2 \mathrm{H}, \mathrm{s},-\mathrm{CH}_{2}-\mathrm{C}=\mathrm{O}\right), 3.59$ $\left(3 \mathrm{H}, \mathrm{s}, \mathrm{O}-\mathrm{CH}_{3}\right) .{ }^{13} \mathrm{C}-\mathrm{NMR}\left(\mathrm{DMSO}-\mathrm{d}_{6}, 75 \mathrm{MHz}\right) \delta \mathrm{ppm}$ : $197.19,171.49,151.23,146.51,145.12,139.78,134.05$, $133.30,131.97,128.95,128.60,113.60,112.03,102.93$, 93.46, 51.98.

Methyl 2-(6-(4-iodobenzoyl)benzo[d][1,3]dioxol-5-yl)acetate (3c) Purified by silica gel column chromatography using $n$-hexane: ethyl acetate solvent system (1:1). Powder product mp: $119-121{ }^{\circ} \mathrm{C}$, Yield $87 \%$. ESI-MS: 424.96 (100), 425.99 (20), for $\mathrm{C}_{17} \mathrm{H}_{14} \mathrm{IO}_{5}$. IR (FTIR/FTNIR-ATR): $1735 \mathrm{~cm}^{-1}$ ester carbonyl $(\mathrm{C}=\mathrm{O}), 1660 \mathrm{~cm}^{-1}$ keton carbonyl $(\mathrm{C}=\mathrm{O}) .{ }^{1} \mathrm{H}$ NMR (DMSO-d $\left.{ }_{6}, 300 \mathrm{MHz}\right) \delta \mathrm{ppm}$ : $7.92(2 \mathrm{H}, \mathrm{d}, J=8.4 \mathrm{~Hz}, \mathrm{Ar}-\mathrm{H}), 7.41(2 \mathrm{H}, \mathrm{d}, J=8.8 \mathrm{~Hz}$, $\mathrm{Ar}-\mathrm{H}), 7.06(1 \mathrm{H}, \mathrm{s}, \mathrm{Ar}-\mathrm{H}), 6.92(1 \mathrm{H}, \mathrm{s}, \mathrm{Ar}-\mathrm{H}), 6.13(2 \mathrm{H}$, $\left.\mathrm{s}, \mathrm{O}-\mathrm{CH}_{2}-\mathrm{O}\right), 3.75\left(2 \mathrm{H}, \mathrm{s},-\mathrm{CH}_{2}-\mathrm{C}=\mathrm{O}\right), 3.47(3 \mathrm{H}, \mathrm{s}, \mathrm{O}-$

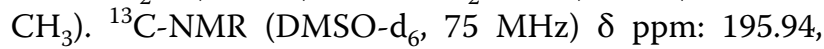
$171.61,149.79,138.52,137.89,137.40,131.94,131.20$, $130.14,112.70,110.38,102.49,102.05,52.02,38.29$.

Methyl 2-(6-(2-bromobenzoyl)benzo[d][1,3]dioxol-5-yl) acetate (3d) Purified by silica gel column chromatography using $n$-hexane: ethyl acetate solvent system (4:1). Powder product, mp: $85-87{ }^{\circ} \mathrm{C}$, Yield $85 \%$; ESI-MS: 377.00 (100), 379 (98), 380 (20), For $\mathrm{C}_{17} \mathrm{H}_{14} \mathrm{BrO}_{5}$. IR (FTIR/FTNIR-ATR): $1740 \mathrm{~cm}^{-1}$ ester carbonyl $(\mathrm{C}=\mathrm{O})$, $1658 \mathrm{~cm}^{-1}$ keton carbonyl $(\mathrm{C}=\mathrm{O}) .{ }^{1} \mathrm{H}$ NMR (DMSO-d $\mathrm{d}_{6}$, $300 \mathrm{MHz}) \delta \mathrm{ppm}: 7.34-7.77(4 \mathrm{H}, \mathrm{m}, \mathrm{Ar}-\mathrm{H}), 7.11(1 \mathrm{H}, \mathrm{s}$, $\mathrm{Ar}-\mathrm{H}), 6.69(1 \mathrm{H}, \mathrm{s}, \mathrm{Ar}-\mathrm{H}), 6.14\left(2 \mathrm{H}, \mathrm{s}, \mathrm{O}-\mathrm{CH}_{2}-\mathrm{O}\right), 3.93$ $\left(2 \mathrm{H}, \mathrm{s},-\mathrm{CH}_{2}-\mathrm{C}=\mathrm{O}\right), 3.59\left(3 \mathrm{H}, \mathrm{s}, \mathrm{O}-\mathrm{CH}_{3}\right) .{ }^{13} \mathrm{C}-\mathrm{NMR}$ $\left(\mathrm{DMSO}_{6}, 75 \mathrm{MHz}\right) \delta \mathrm{ppm}$ : 196.53, 171.61, 149.66, $146.04,138.08,133.39,131.59,130.21,130.00,129.73$, $129.44,128.95,112.66,110.34,102.45,51.89,38.36$.

Methyl 2-(6-(3-bromobenzoyl)benzo[d][1, dioxol-5-yl)acetate (3e) Purified by silica gel column chromatography using $n$-hexane: ethyl acetate solvent system (3:2). Powder product, mp: $72.5-74.5{ }^{\circ} \mathrm{C}$, Yield 79\%; ESI-MS: 377.00 (100), 379 (98), 380 (20), for $\mathrm{C}_{17} \mathrm{H}_{14} \mathrm{BrO}_{5}$. IR (FTIR/FTNIR-ATR): $1742 \mathrm{~cm}^{-1}$ ester carbonyl $(\mathrm{C}=\mathrm{O}), 1655 \mathrm{~cm}^{-1}$ keton carbonyl $(\mathrm{C}=\mathrm{O}) .{ }^{1} \mathrm{H}$ NMR (DMSO-d $\left.{ }_{6}, 500 \mathrm{MHz}\right) \delta \mathrm{ppm}: 7.86(1 \mathrm{H}, \mathrm{d}, J=8 \mathrm{~Hz}$, $\mathrm{Ar}-\mathrm{H}), 7.77(1 \mathrm{H}, \mathrm{s}, \mathrm{Ar}-\mathrm{H}), 7.64(1 \mathrm{H}, \mathrm{d}, J=8 \mathrm{~Hz}, \mathrm{Ar}-\mathrm{H})$, $7.50(1 \mathrm{H}, \mathrm{t}, J=8 \mathrm{~Hz}, \mathrm{Ar}-\mathrm{H}), 7.06(1 \mathrm{H}, \mathrm{s}, \mathrm{Ar}-\mathrm{H}), 6.95(1 \mathrm{H}$, $\mathrm{s}, \mathrm{Ar}-\mathrm{H}), 6.15\left(2 \mathrm{H}, \mathrm{s}, \mathrm{O}-\mathrm{CH}_{2}-\mathrm{O}\right), 3.77\left(2 \mathrm{H}, \mathrm{s},-\mathrm{CH}_{2}-\right.$ $\mathrm{C}=\mathrm{O}), 3.49\left(3 \mathrm{H}, \mathrm{s}, \mathrm{O}-\mathrm{CH}_{3}\right)$.

Methyl 2-(6-(2,4-dichlorobenzoyl)benzo[d][1, 3] dioxol-5-yl)acetate (3f) Purified by silica gel column chromatography using $n$-hexane: ethyl acetate solvent system (1:1). Powder product, mp: $95-97{ }^{\circ} \mathrm{C}$, Yield 83\%; ESI-MS: 367.01 (100), 369 (67), for $\mathrm{C}_{17} \mathrm{H}_{13} \mathrm{Cl}_{2} \mathrm{O}_{5}$. IR (FTIR/FTNIR-ATR): $1760 \mathrm{~cm}^{-1}$ ester carbonyl $(\mathrm{C}=\mathrm{O})$, $1633 \mathrm{~cm}^{-1}$ keton carbonyl $(\mathrm{C}=\mathrm{O}) .{ }^{1} \mathrm{H}$ NMR (DMSO-d $\mathrm{d}_{6}$, $300 \mathrm{MHz}) \delta \mathrm{ppm}: 7.79-7.82(2 \mathrm{H}, \mathrm{m}, \mathrm{Ar}-\mathrm{H}), 7.59(1 \mathrm{H}, \mathrm{d}$, $J=8.4 \mathrm{~Hz}, \mathrm{Ar}-\mathrm{H}), 7.07(1 \mathrm{H}, \mathrm{s}, \mathrm{Ar}-\mathrm{H}), 7.00(1 \mathrm{H}, \mathrm{s}, \mathrm{Ar}-\mathrm{H})$, $6.14\left(2 \mathrm{H}, \mathrm{s}, \mathrm{O}-\mathrm{CH}_{2}-\mathrm{O}\right), 3.78\left(2 \mathrm{H}, \mathrm{s},-\mathrm{CH}_{2}-\mathrm{C}=\mathrm{O}\right), 3.48$ $\left(3 \mathrm{H}, \mathrm{s}, \mathrm{O}-\mathrm{CH}_{3}\right) .{ }^{13} \mathrm{C}-\mathrm{NMR}\left(\mathrm{DMSO}_{6}, 75 \mathrm{MHz}\right) \delta \mathrm{ppm}$ : $194.29,171.68,150.13,146.17,138.56,136.07,131.70$, $131.34,130.62,130.52,130.33,116.68,112.82,110.64$, $102.06,52.05,38.33$.

General synthesis procedure of 2-(6-benzoyl-2H-1,3-benzodioxol-5-yl)acetic acid (4a-4f) The ketoesters 3a-3f ( $450 \mathrm{mg}, 1.35 \mathrm{mmol}$ ) were dissolved in methanol/ $\mathrm{H}_{2} \mathrm{O} /$ THF (12/12/12 mL), then $\mathrm{NaOH}(540.9 \mathrm{mg}, 13.5 \mathrm{mmol})$ was added. The solution was heated in an oil bath and refluxed for $4 \mathrm{~h}$ before being cooled to room temperature. The solution was then evaporated, and the residue was made acidic by adding $\mathrm{HCl} 2 \mathrm{~N}(\mathrm{pH}=2)$. The precipitate was filtered and concentrated under vacuum to give the crude products $\mathbf{4 a}-\mathbf{4 f}$.

2-(6-benzoylbenzo[d][1,3]dioxol-5-yl)acetic acid (4a) Purified by silica gel column chromatography using $n$-hexane: ethyl acetate solvent system (3:2). Powder product, $\mathrm{mp}: 184.5-186.5{ }^{\circ} \mathrm{C}$, Yield 97\%; ESI-MS: 285.07 (100), 286 (20), for $\mathrm{C}_{16} \mathrm{H}_{13} \mathrm{O}_{5}$. IR (FTIR/FTNIRATR): $1770 \mathrm{~cm}^{-1}$ acetic acid carbonyl $(\mathrm{C}=\mathrm{O}), 1655 \mathrm{~cm}^{-1}$ keton carbonyl $(\mathrm{C}=\mathrm{O}) .{ }^{1} \mathrm{H}$ NMR $\left(\mathrm{DMSO}-\mathrm{d}_{6}, 300 \mathrm{MHz}\right)$ $\delta$ ppm: $12.18(1 \mathrm{H}, \mathrm{s}, \mathrm{OH}), 7.49-7.70(5 \mathrm{H}, \mathrm{m}, \mathrm{Ar}-\mathrm{H})$, $7.03(1 \mathrm{H}, \mathrm{s}, \mathrm{Ar}-\mathrm{H}), 6.86(1 \mathrm{H}, \mathrm{s}, \mathrm{Ar}-\mathrm{H}), 6.11(2 \mathrm{H}, \mathrm{s}, \mathrm{O}-$ $\left.\mathrm{CH}_{2}-\mathrm{O}\right), 3.67\left(2 \mathrm{H}, \mathrm{s},-\mathrm{CH}_{2}-\mathrm{C}=\mathrm{O}\right) .{ }^{13} \mathrm{C}-\mathrm{NMR}$ (DMSO$\left.\mathrm{d}_{6}, 75 \mathrm{MHz}\right) \delta$ ppm: 96.64, 172.65, 149.48, 138.12, 133.68, $133.33,131.73,130.68,130.26,130.01,129.20,128.90$, $112.62,110.16,102.32,38.59$.

2-(6-(2-iodobenzoyl)benzo[d][1,3]dioxol-5-yl)acetic acid (4b) Purified by silica gel column chromatography 
using $n$-hexane: ethyl acetate solvent system (3:2). Powder product, mp: $147-149{ }^{\circ} \mathrm{C}$, Yield 92\%; ESI-MS: 410.97 (100), 411 (20), for $\mathrm{C}_{16} \mathrm{H}_{12} \mathrm{IO}_{5}$. IR (FTIR/FTNIR-ATR): $1754 \mathrm{~cm}^{-1}$ acetic acid carbonyl $(\mathrm{C}=\mathrm{O}), 1653 \mathrm{~cm}^{-1}$ keton carbonyl $(\mathrm{C}=\mathrm{O}) .{ }^{1} \mathrm{H}$ NMR $\left(\mathrm{DMSO}-\mathrm{d}_{6}, 300 \mathrm{MHz}\right) \delta \mathrm{ppm}$ : $7.95(1 \mathrm{H}, \mathrm{d}, J=7.8 \mathrm{~Hz}, \mathrm{Ar}-\mathrm{H}), 7.50(1 \mathrm{H}, \mathrm{t}, J=7.8 \mathrm{~Hz}$, Ar-H), 7.23-7.31 (2H, m, Ar-H), $7.06(1 \mathrm{H}, \mathrm{s}, \mathrm{Ar}-\mathrm{H})$, $6.61(1 \mathrm{H}, \mathrm{s}, \mathrm{Ar}-\mathrm{H}), 6.11\left(2 \mathrm{H}, \mathrm{s}, \mathrm{O}-\mathrm{CH}_{2}-\mathrm{O}\right), 3.83(2 \mathrm{H}$, $\mathrm{s},-\mathrm{CH}_{2}-\mathrm{C}=\mathrm{O}$ ). ${ }^{13} \mathrm{C}-\mathrm{NMR}$ (DMSO-d, $\left.75 \mathrm{MHz}\right) \delta \mathrm{ppm}$ : $197.14,172.60,150.97,146.17,145.23,139.81,134.23$, $131.97,129.31,129.14,128.54,113.48,111.77,102.75$, 93.51 .

2-(6-(4-iodobenzoyl)benzo[d][1,3]dioxol-5-yl)acetic acid (4c) Purified by silica gel column chromatography using n-hexane: ethyl acetate solvent system (3:2). Powder product, mp: 239.5-241.5 ${ }^{\circ} \mathrm{C}$, Yield 89\%; ESI-MS: 410.97 (100), 411 (20), for $\mathrm{C}_{16} \mathrm{H}_{12} \mathrm{IO}_{5}$. IR (FTIR/FTNIR-ATR): $1760 \mathrm{~cm}^{-1}$ acetic acid carbonyl $(\mathrm{C}=\mathrm{O}), 1660 \mathrm{~cm}^{-1}$ keton carbonyl $\left(\mathrm{C}=\mathrm{O}\right.$ ). ${ }^{1} \mathrm{H}$ NMR (DMSO- $\left.\mathrm{d}_{6}, 300 \mathrm{MHz}\right) \delta \mathrm{ppm}: 12.20$ $(1 \mathrm{H}, \mathrm{s}, \mathrm{OH}), 7.91(2 \mathrm{H}, \mathrm{d}, J=8.7 \mathrm{~Hz}, \mathrm{Ar}-\mathrm{H}), 7.42(2 \mathrm{H}, \mathrm{d}$, $J=8.4 \mathrm{~Hz}, \mathrm{Ar}-\mathrm{H}), 7.03(1 \mathrm{H}, \mathrm{s}, \mathrm{Ar}-\mathrm{H}), 6.90(1 \mathrm{H}, \mathrm{s}, \mathrm{Ar}-\mathrm{H})$, $6.11\left(2 \mathrm{H}, \mathrm{s}, \mathrm{O}-\mathrm{CH}_{2}-\mathrm{O}\right), 3.67\left(2 \mathrm{H}, \mathrm{s},-\mathrm{CH}_{2}-\mathrm{C}=\mathrm{O}\right) .{ }^{13} \mathrm{C}-$ NMR (DMSO-d 6 , 75 MHz) $\delta$ ppm: 196.04, 172.63, 149.60, $145.85,138.14,137.83,137.44,131.99,131.30,130.77$, $112.63,110.17,102.37,101.95,38.56$.

2-(6-(2-bromobenzoyl)benzo[d][1,3]dioxol-5-yl)acetic acid (4d) Purified by silica gel column chromatography using $n$-hexane: ethyl acetate solvent system (3:2). Powder product, $\mathrm{mp}: 145-147^{\circ} \mathrm{C}$, Yield 87\%; ESI-MS: 362.99 (100), 364 (98), 365 (20) for $\mathrm{C}_{16} \mathrm{H}_{12} \mathrm{BrO}_{5}$. IR (FTIR/ FTNIR-ATR): $1766 \mathrm{~cm}^{-1}$ acetic acid carbonyl $(\mathrm{C}=\mathrm{O})$, $1664 \mathrm{~cm}^{-1}$ keton carbonyl $(\mathrm{C}=\mathrm{O}) .{ }^{1} \mathrm{H}$ NMR (DMSO-d ${ }_{6}$, $300 \mathrm{MHz}) \delta \mathrm{ppm}: 7.41-7.73(4 \mathrm{H}, \mathrm{m}, \mathrm{Ar}-\mathrm{H}), 6.96(1 \mathrm{H}, \mathrm{s}$, $\mathrm{Ar}-\mathrm{H}), 6.61(1 \mathrm{H}, \mathrm{s}, \mathrm{Ar}-\mathrm{H}), 6.07\left(2 \mathrm{H}, \mathrm{s}, \mathrm{O}-\mathrm{CH}_{2}-\mathrm{O}\right), 3.68$ $\left(2 \mathrm{H}, \mathrm{s},-\mathrm{CH}_{2}-\mathrm{C}=\mathrm{O}\right), 3.42(1 \mathrm{H}, \mathrm{bs}, \mathrm{O}-\mathrm{H}) .{ }^{13} \mathrm{C}-\mathrm{NMR}$ $\left(\right.$ DMSO $\left.\mathrm{d}_{6}, 75 \mathrm{MHz}\right) \delta \mathrm{ppm}: 195.59,172.70,150.48$, $133.34,132.50,132.01,130.31,127.99,119.14,112.82$, $112.45,111.03,105.10,102.38,101.57$.

2-(6-(3-bromobenzoyl)benzo[d][1, 3]dioxol-5-yl)acetic acid (4e) Purified by silica gel column chromatography using $n$-hexane: ethyl acetate solvent system (3:2). Powder product, mp: $154-156{ }^{\circ} \mathrm{C}$, Yield 96\%; ESI-MS: 362.98 (100), 364 (98), 365 (20) for $\mathrm{C}_{16} \mathrm{H}_{12} \mathrm{BrO}_{5}$. IR (FTIR/ FTNIR-ATR): $1759 \mathrm{~cm}^{-1}$ acetic acid carbonyl $(\mathrm{C}=\mathrm{O})$, $1658 \mathrm{~cm}^{-1}$ keton carbonyl $(\mathrm{C}=\mathrm{O}) .{ }^{1} \mathrm{H}$ NMR (DMSO$\left.\mathrm{d}_{6}, 300 \mathrm{MHz}\right) \delta \mathrm{ppm}: 12.24(1 \mathrm{H}, \mathrm{s}, \mathrm{O}-\mathrm{H}) 7.75-7.78(2 \mathrm{H}$, $\mathrm{m}, \mathrm{Ar}-\mathrm{H}), 7.64(1 \mathrm{H}, \mathrm{d}, J=8.1 \mathrm{~Hz}, \mathrm{Ar}-\mathrm{H}), 7.48(1 \mathrm{H}, \mathrm{t}$, $J=8.1 \mathrm{~Hz}, \mathrm{Ar}-\mathrm{H}), 7.04(1 \mathrm{H}, \mathrm{s}, \mathrm{Ar}-\mathrm{H}), 6.92(1 \mathrm{H}, \mathrm{s}, \mathrm{Ar}-\mathrm{H})$, $6.12\left(2 \mathrm{H}, \mathrm{s}, \mathrm{O}-\mathrm{CH}_{2}-\mathrm{O}\right), 3.70\left(2 \mathrm{H}, \mathrm{s},-\mathrm{CH}_{2}-\mathrm{C}=\mathrm{O}\right)$. ${ }^{13} \mathrm{C}-\mathrm{NMR}$ (DMSO-d 6 , $\left.75 \mathrm{MHz}\right) \delta \mathrm{ppm}: 195.25,172.72$, $149.80,145.88,140.39,135.85,132.47,131.17,131.09$, $131.04,129.34,122.12,112.70,110.31,102.44,38.58$.

2-(6-(2,4-dichlorobenzoyl)benzo[d][1,3]dioxol-5-yl)acetic acid (4f) Purified by silica gel column chromatography using $n$-hexane: ethyl acetate solvent system (1:1). Solid product, mp: $168.5-170{ }^{\circ} \mathrm{C}$, Yield 91\%; ESI-MS: 352.99 (100), 354 (67) for $\mathrm{C}_{16} \mathrm{H}_{12} \mathrm{Cl}_{2} \mathrm{O}_{5}$. IR (FTIR/FTNIR-ATR): $1768 \mathrm{~cm}^{-1}$ acetic acid carbonyl $(\mathrm{C}=\mathrm{O}), 1657 \mathrm{~cm}^{-1}$ keton carbonyl $(\mathrm{C}=\mathrm{O}) .{ }^{1} \mathrm{H}$ NMR (DMSO-d 6 , $\left.300 \mathrm{MHz}\right) \delta \mathrm{ppm}$ : $12.25(1 \mathrm{H}, \mathrm{s}, \mathrm{OH}), 7.77-7.81(2 \mathrm{H}, \mathrm{m}, \mathrm{Ar}-\mathrm{H}), 7.60(1 \mathrm{H}$, $\mathrm{dd}, J=8.3,1.8 \mathrm{~Hz}, \mathrm{Ar}-\mathrm{H}), 7.05(1 \mathrm{H}, \mathrm{s}, \mathrm{Ar}-\mathrm{H}), 6.98(1 \mathrm{H}$, s, Ar-H), $6.13\left(2 \mathrm{H}, \mathrm{s}, \mathrm{O}-\mathrm{CH}_{2}-\mathrm{O}\right), 3.71\left(2 \mathrm{H}, \mathrm{s},-\mathrm{CH}_{2}-\right.$ $\mathrm{C}=\mathrm{O}$ ). ${ }^{13} \mathrm{C}-\mathrm{NMR}$ (DMSO-d, $\left.75 \mathrm{MHz}\right) \delta \mathrm{ppm}: 194.43$, $172.73,149.41,145.94,138.60,135.99,131.75,131.29$, $131.20,130.74,130.36,129.84,112.74,110.40,102.47$, 38.56 (Additional file 1).

\section{Biological COX assay method}

The ability of the synthesized a series to prevent the conversion of arachidonic acid (AA) to $\mathrm{PGH} 2$ by human recombinant COX2 and bovine COX1 was assessed using a COX inhibitor screening assay kit (Item No: 560131) according to the Cayman chemical manufacturer's guidelines (USA). The $50 \%$ inhibitory concentration $\left(\mathrm{IC}_{50}\right)$ of COX1/COX2 activity of the compounds was carried out. The assay was run in duplicate with three concentrations $(50,20$, and $5 \mu \mathrm{M})$. A standard curve of eight concentrations of prostaglandin, a non-specific binding sample, and a maximum binding sample was used, as instructed in the kit manual, to determine the inhibition of sample compound by applying the multiple regression generated best-fit line. The percentage inhibition of the three concentrations was used to calculate the $\mathrm{IC}_{50}$ [16].

\section{Cell culture and cytotoxicity assay}

HeLa Cervical Carcinoma was cultured in RPMI-1640 media and supplemented with $10 \%$ fetal bovine serum, $1 \%$ penicillin/streptomycin antibiotics and $1 \%$ L-glutamine. Cells were grown in a humidified atmosphere with $5 \% \mathrm{CO}_{2}$ at $37{ }^{\circ} \mathrm{C}$, and they were seeded in $2.6 \times 104$ cells/well in a 96-well plate. After $48 \mathrm{~h}$, the cells were confluent, the media was changed, and cells were incubated with four concentrations $(2,1,0.5$, and $0.2 \mathrm{mM})$ of the tested compounds for $24 \mathrm{~h}$. Cell viability was assessed by the CellTilter $96^{\circledR}$ Aqueous One Solution Cell Proliferation (MTS) Assay according to the manufacturer's instructions (Promega Corporation, Madison, WI). Briefly, at the end of the treatment, $20 \mu \mathrm{L}$ of MTS 
solution per $100 \mu \mathrm{L}$ of media was added to each well and incubated at $37^{\circ} \mathrm{C}$ for $2 \mathrm{~h}$. Absorbance was measured at $490 \mathrm{~nm}$ [37].

\section{Supplementary information}

Supplementary information accompanies this paper at https://doi. org/10.1186/s13065-020-00706-1.

Additional file 1: The data in the addtional file include NMR spectrum files and HRMS file of all newly synthesized compounds described in this article.

\section{Abbreviations}

COX: Cyclooxygenase; FTIR: Fourier-transform infrared spectroscopy; HRMS High resolution mass spectroscopy; ${ }^{1} \mathrm{H}$ NMR: Proton nuclear magnetic resonance; ${ }^{13} \mathrm{C}$ NMR: Carbon nuclear magnetic resonance; $\mu \mathrm{M}$ : Micro molar; $\mathrm{mM}$ : Mili molar; NSAIDs: Non-steroidal anti-inflammatory drugs; ASA: acetyl salicylic acid; WHO: World Health Organization; HeLa: Cervical carcinoma cells; $\mathrm{IC}_{50}$ : $50 \%$ Inhibition concentration; $\mathrm{CC}_{50}: 50 \%$ Cytotoxic concentration; $\mathrm{NaHCO}_{3}$ : Sodium bicarbonate; $\mathrm{NaOH}$ : Sodium hydroxide; DMSO: Dimethyl sulfoxide; AA: Arachidonic acid.

\section{Acknowledgements}

The authors would like to thank An-Najah National University for funding this study (grant number ANNU-1920-Sc013), the Dean of Scientific Research, Gazi University and Anadolu University for their support in chemical analysis.

\section{Authors' contributions}

M.H., N.J., S.H., and A.M. conceived and designed the current study and analyzed the data obtained. This paper was written by M.H., N.J., and S.H., and drafted by all authors. All authors read and approved the final manuscript.

\section{Funding}

This research was supported by the Dean of Scientific Research, An-Najah National University (grant number ANNU-1920-Sc013).

\section{Availability of data and materials}

The datasets used and/or analysed during the current study available from the corresponding author on reasonable request.

\section{Ethics approval and consent to participate}

Not applicable.

\section{Consent for publication}

Not applicable.

\section{Competing interests}

The authors declare that they have no competing interests.

\section{Author details}

${ }^{1}$ Department of Pharmacy, Faculty of Medicine and Health Sciences, An-Najah National University, P.O. Box 7, Nablus 00970, Palestine. ${ }^{2}$ Department of Biomedical Sciences, Faculty of Medicine and Health Sciences, An-Najah National University, Nablus 00970, Palestine.

Received: 8 June 2020 Accepted: 2 September 2020

Published online: 07 September 2020

\section{References}

1. Zarghi A, Arfaei S (2011) Selective COX-2 inhibitors: a review of their structure-activity relationships. Iran J Pharm Res 10(4):655

2. Fiorucci S, Meli R, Bucci M, Cirino G (2001) Dual inhibitors of cyclooxygenase and 5-lipoxygenase. A new avenue in anti-inflammatory therapy? Biochem Pharmacol 62(11):1433-1438
3. Smith WL, Urade Y, Jakobsson PJ (2011) Enzymes of the cyclooxygenase pathways of prostanoid biosynthesis. Chem Rev 111(10):5821-5865

4. Engblom D, Ek M, Saha S, Ericsson-Dahlstrand A, Jakobsson PJ, Blomqvist A (2002) Prostaglandins as inflammatory messengers across the bloodbrain barrier. J Mol Med (Berl). 80(1):5-15

5. Fitzpatrick FA (2004) Cyclooxygenase enzymes: regulation and function. Curr Pharm Des 10(6):577-588

6. Garavito RM, DeWitt DL (1999) The cyclooxygenase isoforms: structural insights into the conversion of arachidonic acid to prostaglandins. Biochim Biophys Acta 1441(2-3):278-287

7. Kirkby NS, Lundberg MH, Harrington LS, Leadbeater PDM, Milne GL, Potter CMF et al (2012) Cyclooxygenase-1, not cyclooxygenase-2, is responsible for physiological production of prostacyclin in the cardiovascular system. Proc Natl Acad Sci 109(43):17597-17602

8. Grosser T, Yu Y, FitzGerald GA (2010) Emotion recollected in tranquility: lessons learned from the COX-2 saga. Annu Rev Med 61(1):17-33

9. Méric J-B, Rottey S, Olaussen K, Soria J-C, Khayat D, Rixe O et al (2006) Cyclooxygenase-2 as a target for anticancer drug development. Crit Rev Oncol Hematol 59(1):51-64

10. Blobaum AL, Marnett $L J$ (2007) Structural and functional basis of cyclooxygenase inhibition. J Med Chem 50(7):1425-1441

11. Hsiao G, Shen M-Y, Chou D-S, Chang Y, Lee L-W, Lin C-H et al (2004) Mechanisms of antiplatelet and antithrombotic activity of midazolam in in vitro and in vivo studies. Eur J Pharmacol 487(1-3):159-166

12. Qneibi $M$, Hamed $O$, Fares $O$, Jaradat $N$, Natsheh $A-R$, AbuHasan $Q$ et al (2019) The inhibitory role of curcumin derivatives on AMPA receptor subunits and their effect on the gating biophysical properties. Eur $J$ Pharm Sci 136:104951

13. Grossi G, Di Braccio M, Roma G, Ballabeni V, Tognolini M, Calcina F et al (2002) 1,5-Benzodiazepines: part XIII. Substituted 4H-[1,2,4] triazolo [4,3-a] $[1,5]$ benzodiazepin-5-amines and 4H-imidazo [1,2-a][1,5] benzodiazepin5-amines as analgesic, anti-inflammatory and/or antipyretic agents with low acute toxicity. Eur J Med Chem 37(12):933-944

14. Liu B, Qu L, Yan S (2015) Cyclooxygenase-2 promotes tumor growth and suppresses tumor immunity. Cancer Cell Int 15(1):106

15. Botting R (2006) Inhibitors of cyclooxygenases: mechanisms, selectivity and uses. J Physiol Pharmacol 57:113

16. Assali M, Abualhasan M, Sawaftah H, Hawash M, Mousa A (2020) Synthesis, biological activity, and molecular modeling studies of pyrazole and triazole derivatives as selective COX-2 inhibitors. J Chem 2020:6393428

17. Ferlay J, Colombet M, Soerjomataram I, Mathers C, Parkin D, Piñeros M et al (2019) Estimating the global cancer incidence and mortality in 2018 . GLOBOCAN sources and methods. Int J Cancer 144(8):1941-1953

18. Hawash M (2019) Highlights on specific biological targets; cyclindependent kinases, epidermal growth factor receptors, Ras protein, and cancer stem cells in anticancer drug development. Drug Res. 69:471-478

19. World Health Organization. Cancer Geneva: WHO; 2018 https://www. who.int/news-room/fact-sheets/detail/cancer. Accessed 29 Aug 2019

20. Hawash M, Baytas S (2017) Antiproliferative activities of some biologically important scaffold. FABAD J Pharm Sci 43(1):59-77

21. Hawash MM, Kahraman DC, Eren F, Cetin Atalay R, Baytas SN (2017) Synthesis and biological evaluation of novel pyrazolic chalcone derivatives as novel hepatocellular carcinoma therapeutics. Eur J Med Chem 129:12-26

22. Bandgar BP, Totre JV, Gawande SS, Khobragade CN, Warangkar SC, Kadam PD (2010) Synthesis of novel 3,5-diaryl pyrazole derivatives using combinatorial chemistry as inhibitors of tyrosinase as well as potent anticancer, anti-inflammatory agents. Bioorg Med Chem 18(16):6149-6155

23. Abu-Hashem AA, El-Shehry MF, Badria FA (2010) Design and synthesis of novel thiophenecarbohydrazide, thienopyrazole and thienopyrimidine derivatives as antioxidant and antitumor agent. Acta Pharm 60:311-323

24. Abdellatif KR, Lamie PF, Omar HA (2016) 3-methyl-2-phenyl-1-substituted-indole derivatives as indomethacin analogs: design, synthesis and biological evaluation as potential anti-inflammatory and analgesic agents. J Enzyme Inhib Med Chem 31(2):318-324

25. Deshpande SR, Nagrale SN, Patil MV, Chavan SS (2015) Novel 3,4-methylenedioxybenzene scaffold incorporated 1,3,5-trisubstituted-2-pyrazolines: synthesis, characterization and evaluation for chemotherapeutic activity. Indian J Pharm Sci 77(1):24-28

26. Rollas S, Küçükgüzel SG (2007) Biological activities of hydrazone derivatives. Molecules 12:1910-1939 
27. Miller EC, Swanson AB, Phillips DH, Fletcher TL, Liem A, Miller JA (1983) Structure-activity studies of the carcinogenicities in the mouse and rat of some naturally occurring and synthetic alkenylbenzene derivatives related to safrole and estragol. Cancer Res 43:1124-1134

28. Lima PC, Lima LM, Silva KCM, Léda PHO, Miranda ALP, Fraga CAM et al (2000) Synthesis and analgesic activity of novel N-acylarylhydrazones and isosters, derived from natural safrole. Eur J Med Chem 35:187-203

29. Khayyat SA (2013) Photosynthesis of dimeric cinnamaldehyde, eugenol, and safrole as antimicrobial agents. J Saudi Chem Soc 17(1):61-65

30. Espahbodinia M, Ettari R, Wen W, Wu A, Shen YC, Niu L et al (2017) Development of novel N-3-bromoisoxazolin-5-yl substituted 2,3-benzodiazepines as noncompetitive AMPAR antagonists. Bioorg Med Chem 25(14):3631-3637

31. Irannejad H, Kebriaieezadeh A, Zarghi A, Montazer-Sadegh F, Shafiee A, Assadieskandar A et al (2014) Synthesis, docking simulation, biological evaluations and 3D-QSAR study of 5-Aryl-6-(4-methylsulfonyl)-3(metylthio)-1,2,4-triazine as selective cyclooxygenase-2 inhibitors. Bioorg Med Chem 22(2):865-873

32. Zarghi A, Ghodsi R (2010) Design, synthesis, and biological evaluation of ketoprofen analogs as potent cyclooxygenase-2 inhibitors. Bioorg Med Chem 18(16):5855-5860

33. Bandyopadhyay S, Pal BC, Parasuraman J, Roy S, Chakrabotry JB, Mukherjee C, et al (2016) Inventors inhibitors of phosphatidylinositol-3-kinase (PI3) and inducers of nitric oxide (NO). United States 2016
34. Qneibi M, Jaradat N, Hawash M, Olgac A, Emwas N (2020) Ortho versus meta chlorophenyl-2,3-benzodiazepine analogues: synthesis, molecular modeling, and biological activity as AMPAR antagonists. ACS Omega 5:3588-3595

35. Jin G, Lee S, Choi M, Son S, Kim GW, Oh JW et al (2014) Chemical genetics-based discovery of indole derivatives as HCV NS5B polymerase inhibitors. Eur J Med Chem 75:413-425

36. çalişkan Ergün B, Nuñe MT, Labeaga L, Ledo F, Darlington J, Bain G et al (2010) Synthesis of 1,5-diarylpyrazol-3-propanoic acids towards inhibition of cyclooxygenase-1/2 activity and 5-lipoxygenase-mediated LTB4 formation. Arzneimittelforschung 60(08):497-505

37. Jaradat NA, Al-lahham S, Zaid AN, Hussein F, Issa L, Abualhasan MN et al (2019) Carlina curetum plant phytoconstituents, enzymes inhibitory and cytotoxic activity on cervical epithelial carcinoma and colon cancer cell lines. Eur J Integrat Med 30:100933

\section{Publisher's Note}

Springer Nature remains neutral with regard to jurisdictional claims in published maps and institutional affiliations.
Ready to submit your research? Choose BMC and benefit from:

- fast, convenient online submission

- thorough peer review by experienced researchers in your field

- rapid publication on acceptance

- support for research data, including large and complex data types

- gold Open Access which fosters wider collaboration and increased citations

- maximum visibility for your research: over $100 \mathrm{M}$ website views per year

At BMC, research is always in progress.

Learn more biomedcentral.com/submissions 